\title{
Urban Strategies Enabling Industrial and Urban Symbiosis: The Case of Slovenia
}

\author{
Lucija Ažman Momirski ${ }^{1, * \mathbb{D}}$, Barbara Mušič ${ }^{2}$ and Boštjan Cotič ${ }^{2}$ \\ 1 Faculty of Architecture, University of Ljubljana, 1000 Ljubljana, Slovenia \\ 2 Urban Planning Institute of the Republic of Slovenia, 1000 Ljubljana, Slovenia; barbaramu@uirs.si (B.M.); \\ bostjanc@uirs.si (B.C.) \\ * Correspondence: lucija.azman@fa.uni-lj.si
}

check for updates

Citation: Ažman Momirski, L.; Mušič, B.; Cotič, B. Urban Strategies Enabling Industrial and Urban Symbiosis: The Case of Slovenia. Sustainability 2021, 13, 4616.

https://doi.org/10.3390/su13094616

Academic Editors: Rita Gamberini and Maria Angela Butturi

Received: 16 March 2021

Accepted: 14 April 2021

Published: 21 April 2021

Publisher's Note: MDPI stays neutral with regard to jurisdictional claims in published maps and institutional affiliations.

Copyright: (c) 2021 by the authors. Licensee MDPI, Basel, Switzerland. This article is an open access article distributed under the terms and conditions of the Creative Commons Attribution (CC BY) license (https:// creativecommons.org/licenses/by/ $4.0 /)$.

\begin{abstract}
Industrial symbiosis (IS) recognizes the exchange of waste resources and by-products between companies that do not normally cooperate in resource exchange; on the other hand, urban symbiosis (UrS) recognizes the use of solid waste in cities as input sources for industries that do not normally accept these sources. It is difficult to realize both in a pre-planned process, and there are few successful initiatives based on the exchange of waste and energy. The main objective of this research is to find out whether there are urban strategies that support the emergence, existence and development of IS and/or UrS in Slovenia. National documents, networks, projects, programs, and national statistical sources were examined. The Integrated Sustainable Urban Development Strategies (ISUSD) for eleven cities and municipalities were reviewed against ten selected indicators. The main findings are that there is intense awareness raising on IS and UrS, and adequate overall legislative support, aligned with EU legislation. Nevertheless, there has been surprisingly less waste conversion to energy recovery since 2010. The reuse of by-products either for energy or new products is non-existent or negligible. Selected main urban strategies for cities in Slovenia are far from setting more concrete guidelines for the development of IS and/or UrS. In the future, more successful integration of IS and UrS is possible in the context of regeneration development of brownfield sites.
\end{abstract}

Keywords: industrial symbiosis; urban symbiosis; circular economy; waste management; waste to energy; Slovenia

\section{Introduction}

Symbiosis is a phenomenon in biology when two different organisms live in a community that is beneficial to both, i.e., coexistence [1]. Frosch and Gallopoulos [2] published the assumption that an industrial ecosystem (the space of an industrial or commercial area) could function analogously to a biological ecosystem (a space where a biological process occurs in nature); in such an industrial system, the use of energy and materials would be optimal, and waste and pollution would be minimized. Industrial symbiosis (IS) has become a recognizable part of the industrial ecology (IE) field [3]. While IE operates at the global, regional, corporate, and enterprise levels [4], the term IS has been used to refer to enterprise linkages [5] that began to develop spontaneously in Kalundborg (Ka) in Denmark in 1961.

IS is defined by the integration of traditionally separate industries into a common approach that involves the physical exchange of materials, energy, water, and/or byproducts to achieve a competitive advantage [4,6]. Christensen [5] also emphasizes that collaboration between different industry partners is essential for IS to achieve shared economic and environmental benefits. The minimum criteria for the IS process are that at least three companies participate in the IS process, exchanging at least two different sources; the process and relationships of IS become complex (circular) rather than linear. Chertow [4] describes the key to successful IS as being based on collaboration and the synergies that result from geographic proximity. The terminology was modified in part by Laybourn $[7,8]$, 
who argues that IS refers not only to industry but also to other organizations or explicitly to non-industry partners such as research and government organizations. Based on practical experience, discussions with contractors and policy makers, Lombardi and Laybourn [8] propose an alternative definition that defines IS as a business opportunity and a tool for eco-innovation: IS operates in a network with diverse eco-innovation organizations and long-term cultural change; knowledge creation, and sharing in the network, triggers mutually profitable transactions to recover necessary inputs, find value-added targets for non-productive products, and improve business and technical processes. According to the authors, geographic proximity, often associated with IS, is neither necessary nor insufficient for IS, nor is it a central focus in the exchange of physical resources. IS is a tool for innovative green growth and eco-efficiency gains are the result of IS, not its driver. To this definition, it can be added that IS becomes a model of sustainability when it can manage four pillars: Eco-Efficiencies, Collaboration, Adaptability, and Proximity [9].

The concept of IS has been extended to the exchange of urban waste and energy from industrial complexes and the development of the concept of urban symbiosis (UrS). The concept of UrS is otherwise very young, having been introduced only in 2009 by Van Berkel et al. [10]. Therefore, most studies focus on IS rather than UrS or a combination of IS and UrS. However, because more and more cities have problems with raw materials, and because many industrial parks are not only an industrial area but also part of an urbanized urban area where people live, UrS is one way to solve the problems [3]. UrS is an extension of IS and is defined as "the use of byproducts (wastes) from cities (or urban areas) as alternative raw materials or energy sources in industrial operations" [11]. The UrS concept is of particular importance in Japan, where solid waste source separation systems are well established in municipal systems and uniquely suited to the Japanese core eco-urban program [12].

The difference between IS and UrS is that the former recognizes the exchange of waste resources and by-products between enterprises that do not normally cooperate in resource exchange; UrS, on the other hand, recognizes the use of solid waste in cities as input sources for industries that do not normally accept these sources [13]. However, both IS and UrS focus on waste recycling and a network of symbioses through feedstock savings and/or emissions reductions that provide obvious benefits to society as a whole [3]. Mulder [14] defines UrS as an innovative strategy to optimize the urban metabolic system. UrS is a physical, economic, and political challenge, but it presents several obstacles, including the complexity of managing the interests of all stakeholders involved.

\subsection{Does IS and/or UrS Arise Spontaneously or Is It Planned?}

Chertow [6] distinguishes between two models of IS formation: the self-organized IS model and the planned IS model, i.e., the eco-industrial park (EIP). A paradigmatic example of the first model is $\mathrm{Ka}$, while the second model is a conscious decision to identify different industrial companies that can share resources in the same location. However, the condition that both technical and economic factors occur in parallel is difficult to realize in a pre-planned process [5].

An industrial zone that establishes an efficient exchange of raw materials and energy between economic units (analogous to nature with little or no waste) is called an EIP or ecoindustrial zone (EIZ). The USPCSD (US President's Council on Sustainable Development) also published a definition of an EIP in 1997: it is a community of businesses that work together with each other, and with the local community, to efficiently share resources (information, materials, water, energy, infrastructure, and natural resources), resulting in economic gain, environmental quality improvement, and equitable human resource enhancement for the business and the local community [6]. Thus, an eco-industrial/commercial zone is a place where industrial symbiotic processes can take place. The USPCSD has otherwise taken a variety of approaches to eco-development, from regional databases to waste parks with subsequent conversion of existing parks to downtown development, rural develop- 
ment, and enhancement of new urban concepts [6]. In Japan, EIPs exist in the form of eco-cities.

As industrial development is a form of economic development, there is interest in IS applications in the form of EIPs for various purposes, including the revitalization of urban and rural sites, including brownfield conversions, and to promote sustainable development [6]. Research on EIPs in the USA and Europe has shown that there are few successful initiatives based on the waste and energy exchange, and that they are difficult to organize [15].

National states in the EU do not implement national plans for IS and/or UrS [16], but they follow the development of the circular economy and the EU documents. More often, actors introduce new local solutions to promote UrS [17]. The key drivers for IS and/or UrS realization are knowledge of the benefits, supportive laws, plans and policies, knowledge of IS and/or UrS practices, trust between actors, and concern for the environment and others [18]. The absence of these drivers, or the reverse process, builds barriers in the IS implementation. The creation of a catalogue for the exchange of IS and/or UrS resources and activities, which can serve as an elementary information/data pool to facilitate the identification of potential IS cooperation partners and further IS activities [19], can initiate further actions and IS and/or UrS connections between suitable cooperation partners.

\subsection{Research on IS and/or UrS in Slovenia}

In Slovenia, the topic of IS is only reflected in written contributions after 2010, but all but one were published in 2015-2020. This means that the subject is quite new on the national level, and its concept and practice is still not well understood [20]. The issues IS addresses are also different from international ones, focusing mainly on actors (e.g., trust building between actors for sharing materials, knowledge, etc.) and spatial issues (e.g., spatial distribution of IS, spatial documents and IS, etc.). We could not find any published research focusing on UrS in Slovenia.

The first such paper starts with reflections on building eco-industrial systems, which includes the principles of IS [21]. Later, a number of papers focus on social actors and IS, emphasizing the links between the information and knowledge society and the ecological aspects of IS, leading to their transformation [22]. Fric continues her interests in a multidisciplinary social approach to the study of IS networks and the influences of socio-cultural factors on the structuring of IS networks, concluding that most IS are underdeveloped and poorly understood $[23,24]$. IS networks cross the boundaries of different systems, which include the social system [25].

Another set of research articles came from the EU project LUMAT (Interreg Central Europe). The Urban Planning Institute of the Republic of Slovenia as one of the project partners also focused on IS issues for green growth and the circular economy. As a result, some issues were discussed and explored: the lack of integration of the IS concept in spatial development strategies, programs, and plans at the regional and local levels, illustrated by the example of Ljubljana [26]; land use inventory and management issues, both of which can contribute to a developed, holistic approach to IS [27]; and the possibilities of introducing IS in the city of Kranj in brownfield redevelopment, especially by improving the attractiveness of (partially) abandoned former industrial areas [28].

The main aim of this work is to find out whether there are urban strategies that support the emergence, existence, and development of IS and/or UrS in Slovenia. To achieve this goal, the research was conducted in several steps: first, through a review of adequate Slovenian national documents, and the diversification and use of the IS and/or UrS concept; then, extracting essential statistical data on IS and/or UrS in the country, followed by an examination of urban strategies, as defined by documents titled Integrated Sustainable Urban Development Strategies, for eleven city municipalities to reveal whether they support the development of IS and/or UrS in relation to the spatial processes.

The principal conclusions highlight intensive awareness raising on IS and UrS through various events and networks. The support of general legislation is adequate and is aligned 
with EU legislation, specifically for waste management processes. Nevertheless, there has been surprisingly less waste conversion to energy recovery since 2010. The reuse of by-products, either for energy or new products, is non-existent or negligible. The selected main strategies for cities in Slovenia are far from setting more concrete guidelines for the development of IS and/or UrS. In the future, more successful integration of IS and UrS is possible in the context of regeneration development of brownfield sites.

\section{Materials and Methods}

In the first phase of the research (Section 3.1 Towards awareness of IS and/or UrS in Slovenia), we used a qualitative method and searched existing reliable documents and similar sources of information to collect relevant data that could probably be used for the research. The data for the first phase is publicly available online. We examined national documents that include the concepts of IS, UrS, and the circular economy; we reviewed networks that promote IS and/or UrS and actively participate in creating favorable conditions for their development; we reviewed European projects or programs based on issues of IS and/or UrS; we followed conferences where contributions on IS and/or UrS were discussed and examples of promotion of the IS, UrS, and circular economy in cities (Table 1). In this type of research, the results tend to be descriptive, and the conclusions are drawn from the data obtained.

The second step (Section 3.2 Waste management in Slovenia; Section 3.2.1 Waste to Energy) was also based on a qualitative method, and the aim was to extract available data on IS and/or UrS from national statistic sources built on reporting data from companies dealing with waste (generated waste and handling of waste). Such reporting is mandatory for companies in Slovenia, and a reporting form is required [29,30]. The data collected on the basis of the Waste Ordinance [31-33] and other waste management regulations that require reporting within the statistical region are also based on data on the location of the waste. Since 2013, Slovenia has also been required to use the IS-Wastes web application to monitor electronic waste. The defined data are not always publicly accessible, but they are sent to researchers on request, and it is important to present them as they give an insight into comparable ratios at the international and national level.

In the third step (Section 3.2.2 By-products as energy source or material reuse), we use the methodology of case study research, which allows an in-depth investigation of IS in their real-life setting.

The fourth step (Section 3.3 Urban policies on IS and/or UrS) was to review selected spatial planning documents in view of IS and/or UrS. The methodology used the following procedure [34]: downloading the latest version of the documents in PDF files from their original sources; using the "Find" command in Acrobat Reader and scanning the page to obtain information about the chapter, paragraph, and sentence containing the selected terms. These were: IS, circular economy, IE, EIP, industrial ecosystems, urban symbiosis, environmental management, synergy, green economy, green governance.

The development of policies and instruments in Slovenia is supported by the Operational Programme for the Implementation of European Cohesion Policy 2014-2020, adopted in 2014 [35]. Due to the possibilities of the Operational Programmes financially supported by the EU, the cities in Slovenia have decided to prepare new strategies and implementation documents, the Integrated Sustainable Urban Development Strategies (ISUSD), which are supported by the Integrated Territorial Investments (ITI) financial mechanism. In Slovenia, eleven city municipalities are eligible for these funds: Ljubljana, Novo mesto, Slovenj Gradec, Velenje, Kranj, Maribor, Ptuj, Celje, Koper, Nova Gorica and Murska Sobota. Guidelines for the ISUDSs enable cities to develop specific urban problem-oriented measures, while the Operational Programme supports measures that simultaneously address several challenges. 
Table 1. List of national documents, networks, EU and other projects, conferences and cities activities referring to IS and/or UrS in Slovenia.

\begin{tabular}{|c|c|c|c|c|c|}
\hline & National Documents & Networks & EU and Other Projects & Conferences & Cities' Activities \\
\hline 2013 & Slovenian Industrial Policy (SIP) & & & $\begin{array}{c}\text { Industrial Symbiosis as an Opportunity for } \\
\text { Slovenia }\end{array}$ & \\
\hline 2014 & $\begin{array}{l}\text { Efficient Use of Resources: Towards } \\
\text { the Slovenian Action Plan }\end{array}$ & & & $\begin{array}{l}\text { Green Industrial Areas: Innovative } \\
\text { Approaches in Urbanism }\end{array}$ & \\
\hline 2015 & $\begin{array}{c}\text { Framework Programme for the } \\
\text { Transition to a Green Economy of } \\
\text { Slovenia } \\
\text { Slovenia's Smart Specialisation } \\
\text { Strategy } \\
\text { Vision of Slovenia } 2050\end{array}$ & & & & \\
\hline 2016 & $\begin{array}{l}\text { Waste Management Programme and } \\
\text { Waste Prevention Programme of the } \\
\text { Republic of Slovenia }\end{array}$ & 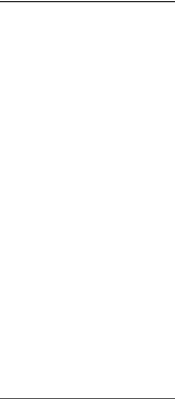 & $\begin{array}{c}\text { Project work with the business and } \\
\text { non-business community in the local } \\
\text { and regional environment } \\
\text { European Circular Construction } \\
\text { Alliance: } \\
\text { adopting Circular Economy for } \\
\text { internationalization and global } \\
\text { competitiveness of European SMEs in } \\
\text { Building and Construction } \\
\text { CEL.KROG }\end{array}$ & & \\
\hline 2017 & Slovenian Development Strategy 2030 & e-Simbioza & $\begin{array}{l}\text { Symbi project } \\
\text { LUMAT }\end{array}$ & $\begin{array}{c}\text { The use of waste as a secondary raw } \\
\text { material—accelerating the transition to a } \\
\text { circular economy with IS } \\
\text { Cities and the Circular Economy-From } \\
\text { urban cases and policies to new } \\
\text { opportunities for cooperation } \\
\text { Let's cooperate. We're networking. Let's } \\
\text { shape... Future } \\
\text { Circular Economy and IS: Incentives, Key } \\
\text { Factors and Challenges } \\
\text { Partnerships for the Green Economy of } \\
\text { Slovenia entitled: Good practices of the } \\
\text { circular economy in the Gorenjska region } \\
\text { and networking with other actors in } \\
\text { Slovenia }\end{array}$ & Circular Exchange \\
\hline
\end{tabular}


Table 1. Cont.

\begin{tabular}{|c|c|c|c|c|c|}
\hline & National Documents & Networks & EU and Other Projects & Conferences & Cities' Activities \\
\hline \multicolumn{6}{|l|}{2018} \\
\hline \multicolumn{6}{|l|}{2019} \\
\hline
\end{tabular}


As a fifth step, in order to predict an IS and/or UrS model and possible scenarios for IS between economic actors in the municipality of Kranj [36], we created a questionnaire to obtain information about open source resources in companies and demand for raw materials as a pre-process of IS and/or UrS. The questionnaire was presented and/or sent to the selected companies in spring 2018.

The questions were:

- Does the company use an internal waste exchange model?

- Does the company use an external waste exchange model?

- Does the company use the generated by-products model?

- Does the company use the generated by-products model for internal use?

- Does the company use the generated model of by-products from external sources?

- Does the company use a business activity model based on IS, such as the online platform for waste exchange between companies?

- Does the company use an IS business model which focuses on product manufacturing?

If any of the answers were positive, we asked the interviewees to describe how this model works in their company.

Two problems arose during the implementation. The first problem was contacting the listed companies, as it involves company trade secrets that most companies do not want to disclose. The second problem was of a substantive nature. The companies are not familiar with the concept of IS and/or UrS and do not understand what it means. Therefore, it was impossible to simply send a questionnaire to companies and expect a response. The surveys were therefore conducted as a discussion or explanation of the characteristics of IS and/or UrS. As a scientific experiment, this approach has failed, although we received some important individual opinions.

\section{Results}

\subsection{Towards Awarness of IS and/or UrS in Slovenia}

The circular economy is one of the goals of the Slovenian Development Strategy $2030[37,38]$, adopted at the end of 2017, which does not recognize IS and/or UrS as a tool to achieve this goal, but gives priority to the sustainable use of energy and sustainable mobility concepts in all sectors.

In 2013, the Slovenian Government adopted the Slovenian Industrial Policy (SIP) [39], which supports the development of the green economy as a driving force based on sustainable and efficient management of renewable and non-renewable resources and energy, and it promotes the use of renewable energy also through the IS concept.

The Ministry of Agriculture and Environment prepared the Efficient Use of Resources: Towards the Action Plan of Slovenia [40] research study in 2014 to obtain information on the state of efficient use of resources from the political and economic perspective. The research uncovered the lack of a unified national vision and sustainable strategy that would support contemporary development trends, including a circular economy and efficient resource use. Based on the findings, Slovenia adopted supporting documents that will help achieve the development goals. One of them is the Framework Programme for the Transition to a Green Economy of Slovenia [41], adopted by the Government of the Republic of Slovenia in 2015, which recognizes the circular economy and the information society as concepts that support the transition to a green economy as a fundamental development orientation.

In 2013, as part of the Slovenia Reduces $\mathrm{CO}_{2}$ : Good Practices project and as part of the preparation of the Slovenian Development Strategy, the Operational Programme for the Use of Structural Funds organized a consultation entitled Industrial Symbiosis as an Opportunity for Slovenia [42]. At the conference, the possibilities of transferring the English IS model (NISP) to Slovenia were pointed out.

The Association of Urban and Spatial Planners of Slovenia, together with the Urban Institute of the Republic of Slovenia, organized the conference Green Industrial Areas: Innovative Approaches in Urbanism [43] in Ljubljana in 2014 as part of the annual Sedlar 
meeting, which included a discussion on IS potentials. The latter was presented by Rachel Lombardi of International Synergies Ltd.

In 2017, there was a larger number of consultations on the circular economy in Slovenia with a focus on IS. The conference of the international project on circular economy, The Use of Waste as a Secondary Raw Material-Accelerating the Transition to a Circular Economy with IS was organized by the Institute of Construction in Slovenia and the project coordinator STORM (IS for Sustainable Management of Raw Materials) ENEA from Italy. Stakeholders exchanged data on available and needed raw materials during the consultation, and as a result, over 100 synergies were recorded [44,45].

In May 2017, the City of Ljubljana and the City of Maribor hosted an international conference on the topic of the circular economy, organized within the framework of the "Circular Exchange" international platform. Among the best cases presented was the "Wcycle company" project from the city of Maribor. As part of the project, most public companies identified 18 circular projects with which they intended to take the lead in the circular economy at the regional level and beyond [46,47].

As part of "Mesec prostora" (The Month of the Space), the month dedicated to spatial planning in October 2017, the Ministry of Environment and Spatial Planning of Republic of Slovenia and the Institute for Spatial Policy in the city of Maribor organized an international conference "Cities and the Circular Economy: From urban cases and policies to new opportunities for cooperation" with the aim of increasing the potential of cities in the transition to a circular economy [48].

In November 2017, the annual international conference of the network of major European cities (EUROCITIES) 2017 was organized in Ljubljana, with the aim of sharing experience and presenting successful cases and practices among cities in the transition to a circular economy. The event was attended by more than 400 participants from 100 cities [49].

In the same month, the annual international symposium of the Society of Paper Technology Engineers and Techniques titled "Let's cooperate. We're networking. Let's shape ... Future" was held, emphasizing networking and mutual cooperation as the basis for establishing a circular economy in the paper and paper-processing industry [50].

Part of the project, titled "Project work with the business and non-business community in the local and regional environment", followed the Creative Path to Knowledge 2016/17 program and an open freely accessible platform, e-Simbioza, was established. The platform enables the construction of ISs based on the exchange of information on waste sources between providers, agents, and customers and is a tool for IS and UrS creation [51].

In November 2017, the Government Office for Development and European Cohesion Policy, as a partner of the Symbi project, IS for Regional Sustainable Growth and an Efficient Circular Economy, organized an international conference titled "Circular Economy and IS: Incentives, Key Factors and Challenges" and a study tour, discussions on financial instruments to promote IS projects and examples of best practice in IS [52]. The Symbi project concluded in December 2020, and its role for the Slovenian pilot case was to "empower stakeholders at the regional level to understand and implement the concept of industrial symbiosis and support companies towards the transition to the circular economy. This concept aims to train the facilitators to be able to support companies to implement industrial symbiosis in practice ... " [53].

\subsection{Waste Management in Slovenia}

According to the waste management hierarchy and with the aim of becoming a "rerecycling society", in Slovenia, waste prevention is the most desirable aim, followed by reuse, material recycling, and energy recovery. It has been recognized that adequate infrastructure is essential for proper waste treatment [54].

Waste processing in Slovenia has increased by $74 \%$ since 2002. In 2008, a total of $68 \%$ of all waste in Slovenia was recycled. In 2008, recycling was ensured for $77 \%$ of waste from production and service activities, for $29 \%$ of municipal waste, and for $47 \%$ of hazardous waste [29]. In Slovenia, about 7 million tons of waste are generated annually. 
The recycling of waste from production and service activities was still around $70 \%$ in recent years. Although the amounts of recycled waste have increased in recent years, the amounts of disposed waste have not decreased. Ensuring a higher proportion of processed waste is important, especially from the point of view of protecting natural resources [29].

In recent years, legislation in the field of waste in Slovenia has been amended and supplemented in accordance with EU requirements. The main regulations governing the area of waste management in Slovenia are the Environmental Protection Act [55], the Waste Management Regulation [56,57], and other legislative measures. The legal requirements are also reflected in the partly high rating of the circular economy in Slovenia in 2016 compared to the EU: In food waste management, the country holds 1st place out of 28; In recycling rate, 2nd place out of 28 ; In trade and recycled raw materials, 2nd place out of 28; In the rate of material reuse, 13th place out of 28; In municipal waste management, Slovenia is 15th out of 28; In private investment in waste management, it holds 20th place out of 28 , and in patents, it is 23rd out of 28 .

The list of the main waste operators depends on the type of waste generated by undertakings in carrying out their production or service activities, and how they are treated is a potential categorization for industrial areas with possible development of IS. The waste receiver in Slovenia can only be a waste collector or processor. Selected categories (Table 2) are defined based on the Waste Regulation [31]:

- Article 42: Waste processors (with an environmental permit for waste processing);

- Article 42: Waste manufacturers (with an environmental permit for waste disposal);

- Article 30: Waste collectors (with a certificate of entry in the register of waste collectors);

- Article 53: Waste managers (with a certificate of entry in the register of waste managers);

- $\quad$ Article 50: Waste dealers (with a certificate of entry in the register of waste dealers).

Table 2. List of the main waste operators in selected municipalities, depending on the type of waste generated by undertakings, in carrying out their production or service activities and waste treatment.

\begin{tabular}{ccccc}
\hline & Kranj $(n)$ & Celje $(n)$ & Novo Mesto $(n)$ & Nova Gorica $(n)$ \\
\hline Processing & 16 & 12 & 11 & 5 \\
Disposal & 2 & 3 & 2 & 0 \\
Collectors & 6 & 12 & 4 & 4 \\
Managers & 5 & 20 & 5 & 4 \\
Dealers & 8 & 21 & 5 & 8 \\
\hline
\end{tabular}

Among the selected municipalities, Celje is the most developed when considering the number of waste operators. This might indicate that there are more opportunities to develop IS and/or UrS in the city than in other compared cities. Processing and handling waste are the primary activities of waste operators in the selected cities.

\subsubsection{Waste to Energy}

In many production processes, material flows are generated that are unsuitable for recycling into production processes. In these cases, the goal of zero waste can only be achieved by converting these streams into energy. The extremely low quality of these material flows requires particularly advanced solutions in the field of energy capture technologies, which then flow back into the processes of the circular economy in the form of energy flows instead of in material form [58].

In 2016, 10 waste incineration plants for the purpose of energy recovery operated in Slovenia, where 231 thousand tons of waste were recovered for energy $(4.2 \%$ of the total waste generated in Slovenia in that year). This was six plants fewer than in 2014 and less waste conversion for energy recovery (269 thousand tons of waste was recovered for energy 
recovery in 2014), although the number of waste treatment plants increased by $3 \%$ between 2014 and 2016 [30].

In a bachelor thesis at the University of Ljubljana, Faculty of Mechanical Engineering [59], it was found that energy from waste is a non-negligible local source of energy production which, at the time of writing, is mainly exported abroad. Slovenia does not have sufficient own capacities for energy recovery from all types and quantities of waste generated. Kevin Mekicar identified the locations of plants in existing technologies that are suitable for waste heat treatment processes and stated that the co-incineration process at the largest capacities in cement and thermal power plants could energetically process all waste generated in Slovenia that is not suitable for recycling or disposal.

\subsubsection{Byproducts as Energy Fuels or Material Reuse}

During the research, no examples of byproducts used as energy fuels were found.

For material reuse, a good example is the case of Sij Acroni d.o.o., a company producing steel and steel products in Jesenice. In the case of Sij Acroni, the IS business model follows the following categorization [36]:

- The IS model is based on byproducts (non-waste residues);

- In 2018, the Sij Group took over the activity and equipment for slag processing of the company Harsco Minerali d.o.o., with which it has already been working closely. The purpose of the acquisition was to consolidate the Sij Group's operations according to the principles of circular economy and vertical integration, as slag-a by-product of steel production-will now be processed by Sij Acroni itself for reuse in production or marketed as input for other industries. In the business model, this means the transition from the model of the company (Harsco Minerali d.o.o.), whose business initiatives are based on IS or IS is the main activity performed by the company, to the model of IS, where the created by-products are used in internal process or are only one part of the company's activities. The aim of the Sij Group is to close material cycles.

Steelmakers are one of the most exemplary examples of the circular economy, producing products from recycled steel and iron.

Another even more important finding took place: in the case of Sij Acroni d.o.o., the IS business model was combined with the spatial development and regeneration of an anthropogenically modified industrial area (buildings + functional areas). The area is not defined as a degraded urban area, as it is not abandoned, although it has some characteristics of a brownfield site. The term "brownfield" is often used to designate former industrial and commercial sites that are either polluted [60], unused and/or abandoned. In addition, a brownfield site may be described as "any land or premises which has previously been used or developed and is not currently fully in use, although it may be partially occupied or utilized" [61]. However, an IS business model that is simultaneously linked to spatial development and regeneration of brownfield sites could become a successful model in the implementation of IS and/or UrS in Slovenia.

\subsection{Urban Policies on IS and/or UrS}

Spatial planning directs the processes in space [62] and controls them according to its procedures and methods. The basic task of spatial planning is placing and arranging activities in space. Spatial plans are legal acts by which the state, region or municipalities set the guidelines for interventions in space and the conditions for their implementation. They are divided by level/criterion and time frame. According to the level/criterion, Slovenia distinguishes between national and municipal spatial plans, and according to the time frame between strategic and implementation plans. Slovenian legislation also mentions the inter-municipal spatial plan as an option and enforces the regional spatial plan, which came into force on 1 June 2018 [63]. Since spatial planning is the responsibility of local municipalities, cities have an important role in implementing spatial planning measures. The essential task of spatial planning is to coordinate different interests or sectors in space. 
The results of the survey of The Integrated Sustainable Urban Development Strategies (ISUSD) of Ljubljana, Novo mesto, Slovenj Gradec, Velenje, Kranj, Maribor, Ptuj, Celje, Koper, Nova Gorica and Murska Sobota [64-74] with selected indicators are surprisingly modest. IS, EIP and UrS are concepts not recognized in these documents (Table 3). The use of the term circular economy mirrors the documents on the national level, as confirmed by previous research (it appears in the Slovenian Development Strategy 2030 (2017) [38], Slovenia's Smart Specialisation Strategy (2015) [75] and the Waste Management Programme and Waste Prevention Programme of the Republic of Slovenia (2016) [76]). This research also confirmed that the indicator IS and/or EIP cannot be found in national spatial documents, such as the Spatial Planning Act (2017) [63].

However, Ljubljana, the European Green Capital 2016, and top recycler among EU capitals, is home to The Regional Waste Management Centre (RCERO) (Figure 1) where the process of biodegradable waste and residual waste of at least 37 Slovenian municipalities that represent one third of the country's population takes place [77]. The products leaving the plant amount to up to 30 thousand tons of raw recyclable materials, up to 60 thousand tons of fuel and 7 thousand tons of compost annually. Non-recyclable materials are processed into fuel, which has a similar calorific value to lignite. The fuel actually consists of parts of untreated waste.

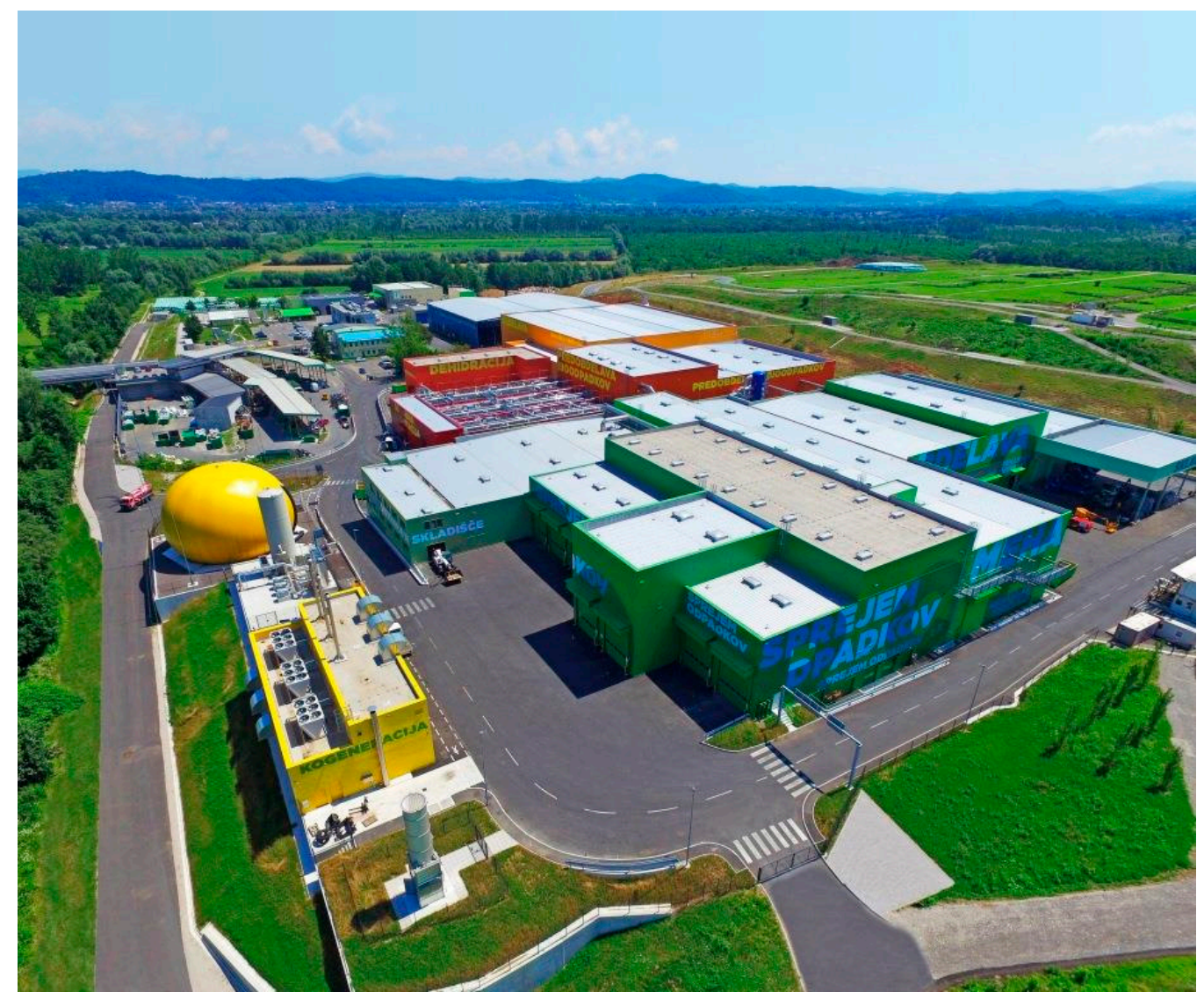

Figure 1. The Regional Waste Management Centre (RCERO) in Ljubljana (Author: SVRK/Črt Slavec, source JP VOKA SNAGA). 
Table 3. Integrated Sustainable Urban Development Strategies (ISUSD) and indicators of IE, IS and UrS.

\begin{tabular}{|c|c|c|c|c|c|c|c|c|c|c|c|}
\hline & Ljubljana & Novo Mesto & $\begin{array}{l}\text { Slovenj } \\
\text { Gradec }\end{array}$ & Velenje & Kranj & Maribor & Ptuj & Celje & Koper & Nova Gorica & $\begin{array}{c}\text { Murska } \\
\text { Sobota }\end{array}$ \\
\hline industrial symbiosis (IS) & no & no & no & no & no & no & no & no & no & no & no \\
\hline circular economy & no & yes & no & no & yes & yes & no & no & no & no & yes \\
\hline eco-industrial park (EIP) & no & no & no & no & no & no & no & no & no & no & no \\
\hline industrial ecosystems & no & no & no & no & no & no & no & no & no & no & no \\
\hline urban symbiosis & no & no & no & no & no & no & no & no & no & no & no \\
\hline $\begin{array}{c}\text { environmental } \\
\text { management }\end{array}$ & no & no & no & no & no & no & no & no & no & no & no \\
\hline synergy & yes & yes & no & no & no & no & no & no & no & no & no \\
\hline green economy & yes & no & no & no & no & no & no & no & no & no & no \\
\hline green governance & no & no & no & no & yes & no & no & no & no & no & no \\
\hline
\end{tabular}




\section{Discussion}

Assessing academic articles and public events such as conferences, awareness of IS has only really grown in recent years in Slovenia. Despite some recognition of the potentials of IS as a sustainable concept in some of the development documents of Slovenia, IS is not included in the strategic spatial development documents as a direction or a measure for the efficient management of the resources on which Slovenia is dependent. Although both IS and/or UrS are already recognized as contemporary concepts in Europe [78-80], it is unfortunately not yet so in Slovenia. The concept of UrS is missing completely.

The integration of IS and/or UrS in Slovenia remains only at the level of orientations, although integration attempts in the Slovenian space can be seen through European projects such as LUMAT. Its pilot action in Slovenia explored the non-systematic management of degraded urban areas and business zones in the Municipality of Kranj. The objective was to stimulate IS based on the management of industrial sites, by directing IS development within already urbanized areas and limiting interventions in greenfield areas. Various scenarios for different models of IS were presented in the selected pilot area of the Municipality of Kranj, depending on the:

- Locations of economic operators;

- Locations of degraded urban areas and

- Locations of business zones.

Traditionally, municipalities have planned special areas for industrial, commercial, agricultural, recreational, and other purposes as well as for residential areas. Furthermore, the planning of business zones is carried out on the basis of various starting points and objectives [81]. However, as shown in the case study of Sij Acroni d.o.o., an IS business model that is simultaneously linked to spatial development and regeneration of brownfield sites could become a successful model in the implementation of IS and/or UrS in Slovenia. Such an approach could add to spatial planning processes, which have, so far, not aimed toward IS and/or UrS, but simply any industry and/or any other activity.

The identification of development potentials and methods, tools and instruments suitable for Slovenia, based on successful examples of good practice in both IS and/or UrS, could focus primarily on stakeholder involvement and education. As Rončevič and Fric [20] also note, the concept and practice of IS is not well understood even within a small sample of organizations actively involved in waste management. This finding is similar to our experience in the fifth step of the research. It seems that the success of implementing IS and/or UrS in Slovenia is not to distance oneself from considering IS only as a business model, but to focus on the actors and stakeholders, their cooperation, trust building and information exchange. This delicate field of action and research is a necessary basis for the further development of IS and/or UrS in Slovenia, and its inclusion in space, where co-design, participatory planning processes and negotiations are starting to become part of urban strategies.

Regarding the reaction of companies to the online platform for sharing information on waste and byproducts between companies, we again came to similar conclusions as those of Rončevič and Fric [20]. Companies would await this opportunity to create future collaborations and possible IS and/or UrS with great interest, as such online tools would allow them to optimize their search for potential IS actors with relevant types of byproducts, or waste materials, for exchange.

\section{Conclusions}

One of the flagship initiatives of EU2020, the European framework development strategy, is to promote sustainable growth based on resource-efficient management. Due to the limitation of the excessive use of natural resources, in 2011, the European Commission adopted the document "Roadmap to a Resource Efficient Europe", which recognizes IS as a tool to promote effective production that encourages the reuse of raw materials. In order to promote sustainable production and consumption, the EC tells member states that they must help companies to cooperate in creating sustainable models, as is the concept of 
IS [82]. It seems that this process is still in its early stages in Slovenia, so urban strategies that include IS and/or UrS will integrate both concepts more slowly than expected.

Author Contributions: Conceptualization, L.A.M. and B.M.; methodology, L.A.M.; formal analysis, L.A.M., B.M. and B.C.; investigation, L.A.M., B.M. and B.C.; resources, L.A.M., B.M. and B.C.; data curation, L.A.M., B.M. and B.C.; writing—original draft preparation, L.A.M., B.M. and B.C.; writingreview and editing, L.A.M., B.M. and B.C.; visualization, L.A.M.; project administration, L.A.M. All authors have read and agreed to the published version of the manuscript.

Funding: This research was partly funded by project LUMAT (Implementation of Sustainable Land Use in Integrated Environmental Management of Functional Urban Areas), Project number: CE89, funded under the programme INTERREG CENTRAL EUROPE. The authors also acknowledge the financial support from the Slovenian Research Agency (research core funding No. P5-0100).

Institutional Review Board Statement: Not applicable.

Informed Consent Statement: Not applicable.

Data Availability Statement: Data available in a publicly accessible repositories that do not issue DOIs.

Conflicts of Interest: The authors declare no conflict of interest.

\section{References}

1. Fran. Available online: https:/ / fran.si/ (accessed on 1 January 2021).

2. Frosch, R.A.; Gallopoulos, N.E. Strategies for manufacturing. Sci. Am. 1989, 261, 144-152. [CrossRef]

3. Dong, L.; Fujita, T.; Zhang, H.; Dai, M.; Fujii, M.; Ohnishi, S.; Geng, Y.; Liu, Z. Promoting low-carbon city through industrial symbiosis: A case in China by applying HPIMO model. Ener. Pol. 2013, 61, 864-873. [CrossRef]

4. Chertow, M.R. Industrial symbiosis: Literature and taxonomy. Annu. Rev. Energy Environ. 2000, 25, 313-337. [CrossRef]

5. Ehrenfeld, J.R.; Gertler, N. Industrial ecology in practice: The evolution of interdependence at Kalundborg. J. Ind. Ecol. 1997, 1, 67-79. [CrossRef]

6. Chertow, M.R. Uncovering industrial symbiosis. J. Ind. Ecol. 2007, 11, 11-30. [CrossRef]

7. Laybourn, P. The Development of the National Industrial Symbiosis Program (NISP)—A Case for Publicly Funded Macro Industrial Symbiosis Networks; Presentation to Intellegant: Made for the Future: Cambridge, UK, 12 March 2006.

8. Lombardi, D.R.; Laybourn, P. Redefining Industrial Symbiosis. J. Ind. Ecol. 2012, 16, 28-37. [CrossRef]

9. Diemer, A. Industrial symbiosis and european policy. In European Union and Sustainable Development: Challenges and Prospects; Diemer, A., Morales, M.E., Eds.; Editions Oeconomia, Imprimerie Chaumeil: Clermont-Ferrand, France, 2017; pp. 235-258.

10. Van Berkel, R.; Fujita, T.; Hashimoto, S.; Geng, Y. Industrial and urban symbiosis in Japan: Analysis of the Eco-Town program 1997-2006. J. Environ. Manag. 2009, 90, 1544-1556. [CrossRef] [PubMed]

11. Dong, L. Achieving carbon emission reduction through industrial \& urban symbiosis: A case of Kawasaki. Energy 2014, 64, 277-286.

12. Geng, Y.; Tsuyoshi, F.; Chen, X. Evaluation of innovative municipal solid waste management through urban symbiosis: A case study of Kawasaki. J. Clea. Prod. 2010, 18, 993-1000. [CrossRef]

13. Chen, X.; Xi, F.; Geng, Y.; Fujita, T. The potential environmental gains from recycling waste plastics: Simulation of transferring recycling and recovery technologies to Shenyang, China. Waste Man. 2011, 31, 168-179. [CrossRef]

14. Mulder, K. Urban symbiosis as a strategy for sustainabilising cities: An overview of options and their potential, pitfalls and solutions. Civil Eng. Res. J. 2017, 2, 1-7. [CrossRef]

15. Gibbs, D.; Deutz, P. Reflections on implementing industrial ecology through eco-industrial park development. J. Clean. Prod. 2007, 15, 1683-1695. [CrossRef]

16. Czaplicka-Kotas, A.; Kulczycka, J.; Iwaszczuk, N. Energy clusters as a new urban symbiosis concept for increasing renewable energy production-A case study of zakopane city. Sustainability 2020, 12, 5634. [CrossRef]

17. Vernay, A.L.; Mulder, K.F. Organising urban symbiosis projects. In Proceedings of the Institution of Civil Engineers-Engineering Sustainability; Thomas Telford Ltd.: London, UK, 2015; Volume 169, pp. 181-188.

18. Neves, A.; Godina, R.; Azevedo, S.G.; Pimentel, C.; Matias, J.C.O. The potential of industrial symbiosis: Case analysis and main drivers and barriers to its implementation. Sustainability 2019, 11, 7095. [CrossRef]

19. Rohde-Lütje, A.; Wohlgemuth, V. Recurring patterns and blueprints of industrial symbioses as structural units for an IT tool. Sustainability 2020, 12, 8280. [CrossRef]

20. Fric, U.; Rončević, B. E-simbioza: Leading the way to a circular economy through industrial symbiosis in Slovenia. Soc. Ecol. J. Ecol. T. Soc. R. 2018, 27, 119-140. [CrossRef]

21. Krajnc, D. The establishment of eco-industrial systems including the principles of industrial symbiosis. In Waste in Slovenia; Černuta, U., Ed.; Fit Media: Celje, Slovenia, 2010; pp. 203-212. 
22. Fric, U. Transformation of ecological aspects of industrial symbiosis in post-industrial society. Res. Soc. Chan. 2015, 7, 349-372.

23. Fric, U. Socio-cultural aspects and barriers of industrial symbiosis-The good, the bad and the ugly: Which ones matter and why? In Proceedings of the 4th International Conference on Economics, Political and Law Science, Rome, Italy, 7-9 November 2015; pp. 125-131.

24. Fric, U. Socio-cultural factors of industrial symbiosis: Conceptualization and research approach. Int. J. Enery Environ. 2016, 10, 70-76.

25. Fric, U.; Rončević, B.; Uršič, E.D. Role of computer software tools in industrial symbiotic networks and the examination of sociocultural factors. Environ. Pro. Sust. E 2020, 39, e13364. [CrossRef]

26. Mušič, B. Urban planning and industrial symbiosis in Slovenia. In Proceedings of the 3rd World Multidisciplinary Civil Engineering, Architecture, Urban Planning Symposium (WMCAUS 2018); Prague, Czech Republic, 18-22 June 2018, IOP: Bristol, UK, 2019; Volume 471, pp. 1-9. [CrossRef]

27. Ažman Momirski, L. Industrial symbiosis and land use. In Proceedings of the 3rd World Multidisciplinary Civil Engineering, Architecture, Urban Planning Symposium (WMCAUS 2018); Prague, Czech Republic, 18-22 June 2018, IOP: Bristol, UK, 2019; Volume 471, pp. 1-9. [CrossRef]

28. Cotič, B. Industrial symbiosis in brownfields in Kranj, Slovenia. In Proceedings of the 3rd World Multidisciplinary Civil Engineering, Architecture, Urban Planning Symposium (WMCAUS 2018), Prague, Czech Republic, 18-22 June 2018; IOP: Bristol, UK, 2019; Volume 471, pp. 1-9. [CrossRef]

29. Slovenian Environmental Agency. Available online: https://www.arso.gov.si/varstvo\%20okolja/odpadki/obrazci/ (accessed on 28 February 2021).

30. Statistical Office of Republic of Slovenia. Available online: https:/ / www.stat.si/StatWeb/Field/Index/13/70 (accessed on 28 February 2021).

31. Waste Regulation. Official Gazette of the Republic of Slovenia, No. 37/2015. Available online: https://www.uradni-list.si/ glasilo-uradni-list-rs/vsebina/2015-01-1513/uredba-o-odpadkih (accessed on 31 January 2021).

32. Official Gazette of the Republic of Slovenia, No. 69/2015. Available online: https:/ /www.uradni-list.si/glasilo-uradni-list-rs / vsebina/2015-01-2767/uredba-o-spremembah-in-dopolnitvah-uredbe-o-odpadkih (accessed on 31 January 2021).

33. Official Gazette of the Republic of Slovenia, No. 129/2020. Available online: https:/ / www.uradni-list.si/glasilo-uradni-list-rs / vsebina/2020-01-2317?sop=2020-01-2317 (accessed on 31 January 2021).

34. Oliviera, E.H.d.S. Place branding in strategic spatial planning: A content analysis of development plans, strategic initiatives and policy documents for Portugal. J. Place Man. A Dev. 2015, 8, 23-50. [CrossRef]

35. Operational Programme for the Implementation of European Cohesion Policy 2014-2020. Available online: https:/ / eu-skladi.si/ sl/dokumenti/kljucni-dokumenti/op_ang_final_web.pdf (accessed on 27 November 2020).

36. Ažman Momirski, L. Znanstveno Strokovno Gradivo o Industrijskih Simbiozah: Zaključno Poročilo; Lasscan: Ljubljana, Slovenia, 2018.

37. Strategija Razvoja Slovenije. 2020. Available online: https://www.gov.si/assets/vladne-sluzbe/SVRK/Strategija-razvojaSlovenije-2030/Strategija_razvoja_Slovenije_2030.pdf (accessed on 31 January 2021).

38. Slovenia Development Strategy 2030: Prospects, Challenges and Policy Options to Achieve the Main Objectives. Available online: https:/ /issuu.com/oecd.publishing/docs/slovenia-development-strategy-2030 (accessed on 31 January 2021).

39. The Slovenian Industrial Policy. Available online: Vrs-3.vlada.si/VLADNAGRADIVA.NSF/VG-SIP (accessed on 31 January 2021).

40. Efficient Use of Resources: On the Way to the Action Plan of Slovenia. Available online: http://mop.arhiv-spletisc.gov.si/ fileadmin/mop.gov.si / pageuploads/podrocja/odpadki/ucinkovita_raba_virov.pdf (accessed on 26 November 2020).

41. Framework Program for the Transition to the Green Economy of Slovenia. Available online: http://vlada.arhiv-spletisc.gov.si/ fileadmin/dokumenti/si/projekti/2016/zeleno/opzg_akcijski_nacrt_in_nacrt_aktivnosti.pdf (accessed on 18 December 2020).

42. Industrial Symbiosis as an Opportunity for Slovenia. Available online: www.slovenija-co2.si/upload/mediji_nisp_17092013.doc (accessed on 18 November 2020).

43. Sedlarjevo Srečanje. Available online: https://www.zaps.si/index.php?m_id=DOGODKI\&date=13.06.2014 (accessed on 18 November 2020).

44. STORM: Industrial Symbiosis for the Sustainable Management of Raw Materials. Available online: http:/ /www.storm-eitrm.eu/ (accessed on 18 November 2020).

45. Konferenca o Krožnem Gospodarstvu. Available online: http://www.zag.si/si/novice/konfrenca-o-kroznem-gospodarstvu (accessed on 18 November 2020).

46. V Mariboru o Krožnem Gospodarstvu s Poudarkom na Nujnosti Sistemskih Sprememb. Available online: http://www.lokalec. si/novice/v-mariboru-o-kroznem-gospodarstvu-s-poudarkom-na-nujnosti-sistemskih-sprememb/ (accessed on 18 November 2020).

47. Wcycle. Available online: https://wcycle.com/en/wcycle-english/ (accessed on 25 February 2021).

48. Mesta v Ospredju pri Prehodu na Krožno Gospodarstvo. Available online: http:/ /ipop.si/2017/10/20/mesta-v-ospredju-priprehodu-na-krozno-gospodarstvo/ (accessed on 18 November 2020).

49. EUROCITIES 2017 Ljubljana-Circular Cities. Available online: http://www.eurocities.eu/eurocities/allcontent/EUROCITIES2017-Ljubljana-circular-cities-WSPO-AKHBYP (accessed on 18 November 2020). 
50. Sodelujemo. Mrežimo. Sooblikujemo ... Prihodnost. 21. Dan Slovenskega Papirništva \& 44. Mednarodni Letni Simpozij DITP-22. in 23. November 2017. Available online: http:/ / celkrog.si/sodelujemo-mrezimo-sooblikujemo-prihodnost/ (accessed on 18 November 2020).

51. E-SIMBIOZA, e-Platforma za Podporo Krožnemu Gospodarstvu Slovenije. Available online: http://esimbioza.fis.unm.si/ (accessed on 18 November 2020).

52. Konferenca Symbi, Z Industrijsko Simbiozo do Lažjega Prehoda v Krožno Gospodarstvo. Available online: http:/ / www.euskladi.si/sl/aktualno/novice/z-industrijsko-simbiozo-do-lazjega-prehoda-v-krozno-gospodarstvo (accessed on 18 November 2020).

53. Symbi: Slovenia Pilot News. Available online: https://www.interregeurope.eu/symbi/news/news-article/9165/slovenia-pilotnews / (accessed on 31 January 2021).

54. Infrastructure for Waste Management. Available online: https://www.stat.si/StatWeb/en/news/Index/7501 (accessed on 26 February 2021).

55. Environmental Protection Act. Available online: http:/ / pisrs.si / Pis.web / pregledPredpisa?id=ZAKO1545 (accessed on 31 January 2021).

56. Waste Management Regulation. Official Gazette of the Republic of Slovenia, No. 34/2008. Available online: https:/ /www.uradnilist.si / glasilo-uradni-list-rs /vsebina/2008-01-1358?sop=2008-01-1358 (accessed on 26 February 2021).

57. Official Gazette of the Republic of Slovenia, No. 103/2011. Available online: https:/ / www.uradni-list.si/glasilo-uradni-list-rs / vsebina / 2011-01-4514?sop=2011-01-4514 (accessed on 26 February 2021).

58. Zero Waste. Available online: https:/ / celkrog.si/kljucni-pojmi/nic-odpadkov/ (accessed on 5 February 2021).

59. Mekicar, K. Termična Obdelava Odpadkov v Sloveniji: Diplomsko delo Visokošolskega Strokovnega Študijskega Programa I. Stopnje Strojništvo. Available online: https:/ / repozitorij.uni-lj.si/IzpisGradiva.php?id=118607 (accessed on 5 February 2021).

60. US Environmental Protection Agency. Brownfields and Land Revitalization. Available online: http://www.epa.gov/brownfields/ (accessed on 18 November 2020).

61. Alker, S.; Joy, V.; Roberts, P.; Smith, N. The definition of brownfield. J. Environ. Plan. A Man. 2000, 43, 49-69. [CrossRef]

62. Ažman Momirski, L. Urbanistične delavnice: Uveljavljeno orodje v vsakdanji praksi prostorskega načrtovanja. In Oblike Prostorskega Načrtovanja: Od Mestnega Načrta do Urejanja Naselij; Ažman Momirski, L., Fikfak, A., Eds.; Fakulteta za Arhitekturo: Ljubljana, Slovenia, 2002; pp. 54-55.

63. Zakon o Urejanju Prostora (ZUreP-2). Available online: https://www.uradni-list.si/glasilo-uradni-list-rs/vsebina/2017-01-2915 (accessed on 5 February 2021).

64. Trajnostna Urbana Strategija Mestne Občine Ljubljana 2014-2020. 2015. Available online: https://www.ljubljana.si/assets/Seje/ 15486/sprejeta-tus-strmol.pdf (accessed on 31 January 2021).

65. Trajnostna Urbana Strategija Novo Mesto 2030. 2015. Available online: https://www.novomesto.si/mma/-/2017091316031533/ (accessed on 31 January 2021).

66. Trajnostna Urbana Strategija Mesta Slovenj Gradec-TUS MSG 2015-2030. 2015. Available online: https:/ / www.slovenjgradec. si/media/uploads/files/TUS/Trajnostna\%20urbana\%20strategija\%20MSG_20151102.pdf (accessed on 31 January 2021).

67. Trajnostna Urbana Strategija za Pametno, Podjetno in Prijazno Velenje 2025. 2015. Available online: https: / dokumen.tips / documents / trajnostna-urbana-strategija-za-pametno-podjetno-in-velenje-2025pdf-trajnostna.html (accessed on 31 January 2021).

68. Trajnostna Urbana Strategija Mestne Občine Kranj. Novelirana in Preoblikovana Strategija Trajnostnega Razvoja Mestne Občine Kranj 2009-2023, Predlog. 2015. Available online: https:/ /www.kranj.si/files/01_kranj_moje_mesto/tus2030/MO-Kranj-TUS. pdf (accessed on 31 January 2021).

69. Trajnostna Urbana Strategija Mestne Občine Maribor. 2015. Available online: https:/ /www.maribor.si/dokument.aspx?id=28079 (accessed on 31 January 2021).

70. Vizija in Strategija Mestne Občine Ptuj 2015-2025, Trajnostna Urbana Strategija. 2015. Available online: http:/ /arhiv.e-obcina.si/ ptuj31122020/www.ptuj.si/_pdf/Vizija_in_strategija_Mestne_obcine_Ptuj_2015-2025.pdf (accessed on 31 January 2021).

71. Trajnostna Urbana Strategija Mestne Občine Celje, 2015-2030. 2015. Available online: https://www.zmos.si/wp-content/ uploads/2019/01/MO-Celje-IN-TUS-s-sklepom.pdf (accessed on 31 January 2021).

72. Trajnostna Urbana Strategija Mesta Koper. 2016. Available online: https://www.koper.si/wp-content/uploads/2020/06/TUSKoper-FEB-2016.pdf (accessed on 31 January 2021).

73. Trajnostna Urbana Strategija Nova Gorica 2020. 2016. Available online: https://www.nova-gorica.si/mma/trajnostna_urbana_ strategija_nova_gorica_tus_2020/2015102414144291/?m=1445688885 (accessed on 31 January 2021).

74. Trajnostna Urbana Strategija Mestne Občine Murska Sobota. 2015. Available online: https://murska-sobota.si/sites/default/ files/datoteke/Trajnostna\%20urbana\%20strategija\%20Mestne\%20ob\%C4\%8Dine\%20Murska\%20Sobota.pdf (accessed on 31 January 2021).

75. Smart Specialisation Strategy of the Republic of Slovenia. 2015. Available online: https://www.sbra.be/sites/default/files/ Smart\%20Specialisation\%20Strategy\%20of\%20Rep\%20of\%20Slovenia.pdf (accessed on 7 January 2021).

76. Waste Management Programme and Waste Prevention Programme of the Republic of Slovenia. 2016. Available online: https: //www.gov.si/assets/ministrstva/MOP/Operativni-programi/op_odpadki.pdf (accessed on 7 January 2021).

77. Ljubljana Regional Waste Management Centre. Available online: https://www.vokasnaga.si/en/Regional\%20Waste\%20 Management $\% 20$ Centre (accessed on 31 January 2021). 
78. Martinho, V.D.; Mourão, P.R. Circular Economy and Economic Development in the European Union: A Review and Bibliometric Analysis. Sustainability 2020, 12, 7767. [CrossRef]

79. Ferraz, D.; Falguera, F.P.S.; Mariano, E.B.; Hartmann, D. Linking economic complexity, diversification, and industrial policy with sustainable development: A structured literature review. Sustainability 2021, 13, 1265. [CrossRef]

80. Rincón-Moreno, J.; Ormazabal, M.; Álvarez, M.J.; Jaca, C. Shortcomings of transforming a local circular economy system through industrial symbiosis: A case study in Spanish SMEs. Sustainability 2020, 12, 8423. [CrossRef]

81. Čok, G.; Kavaš, D.; Zimmermann, R. Business zones in Slovenian and Croatian Istria: Locations, capacity and development problems. Prostor 2016, 24, 254-267. [CrossRef]

82. Časovni Okvir za Evropo, Gospodarno z Viri. Available online: https://eur-lex.europa.eu/legal-content/SL/TXT/?uri=CELEX\% 3A52011DC0571 (accessed on 26 February 2021). 